\title{
Foreign Aid to Timor-Leste and the Rise of China
}

\author{
Cristian Talesco \\ Hong Kong Polytechnic University \\ Hong Kong
}

\begin{abstract}
Foreign aid forms an important part of a state's identity within the international system. The established dichotomy saw developed countries giving aid, while developing countries were receiving it. Nevertheless, China's 'rise', along with that of other 'emerging economies', changed such a dualist view; or at least undermined the traditional concept of aid giving. China is becoming a world power, it is the second largest economy, yet it is still within the group of developing countries. However, it provides a considerable amount of foreign aid worldwide. This is destabilizing the established understandings of aid regimes, as set by the Development Assistance Committee (DAC) donors since the 1950s. In particular, the rise of China in Timor-Leste as an important aid contributor, but working outside the leading aid regime, is affecting the most prominent donor in the country, Australia. Moreover, the rapidly growing presence of China in Timor-Leste seems well received by the local government, although criticism arose amongst the population. Thus, this paper attempts to analyse the issue from different levels. Firstly, it will analyse how China managed to "break" the monopoly of Australian aid by accessing Timor-Leste. It will then explicate the principles and the practices of Chinese aid, and will attempt to establish whether Chinese aid has produced a positive economic impact on Timor-Leste and its people. Finally, this paper suggests that Chinese aid is not challenging, neither threatening the Australian aid assistance in Timor-Leste; rather Chinese aid offers an alternative way of giving aid, and which can also convey to Australia with the possibilities of establishing mutual benefits and effective partnerships with the recipient countries.
\end{abstract}

Keywords: Foreign aid, China, Australia, Timor-Leste, Development.

\section{Introduction}

Southeast Asia is a sort of "battlefield" for Australia and China in the light of current trade and business opportunities offered by the region. Australia is the "European sister" in Oceania. It shares the Western values in its foreign policy, and it contributes to the spread of the concept of democracy and human rights in Southeast Asia and the Pacific region. Australia has helped several countries in the region during severe financial problems. This includes the Solomon Islands, Nauru, Papua New Guinea, and Timor-Leste. Australia has its own strategic reasons in giving aid and does not pose any problem with the China's aid programme. Until recently, with China concerned with its own internal problems, it was quite easy for Australia to push its own agenda throughout Southeast Asia with her 
aid programmes. However, with the rise of China, the balance of power in aid giving has changed dramatically. Developing countries now get aid from alternative sources. This has affected Australia's plans, especially with regard to Timor-Leste, where it has pushed the local government to allow for the construction of migrants' facilities which the Timor-Leste government had all along been completely against. This sort of aggressive and bullying tactic by Australia to Timor-Leste has been in practise until recently, when China moved in with aid to Timor-Leste. This has destabilized the role of Australia by juxtaposing it against China, which provides aid to the country without preconditions. This opens a debate over the future relationship of Timor-Leste with China and Australia, the two most powerful countries in the Asia-Pacific area but with each having very different approaches, and values.

\section{Defining Foreign Aid: An Australian and a Chinese Perspective}

This paper deals with two aid donors, namely China and Australia, which have different approaches in delivering aid assistance. As such, a definition of key terms is vital although due to China's secrecy and concealment, it refuses to provide sufficient information, data or white paper to clearly define what China intends as development assistance, and why it is providing such hefty assistance to so many strategically placed countries.

Generally speaking, foreign aid is a very broad term, and scholars have given it many interpretations.(Riddel, 2007; Davies et al. 2008; Brautigam, 2008) What is common, however, is that foreign aid is intended as a form of support, and help given by one nation to another for the purpose of development.

The concept of aid is different between Australia, which is part of the Development Assistance Committee (DAC), and China. The DAC definition of aid has been published in several papers of the Organisation for Economic Co-operation and Development (OECD) and it is a definition built on the agreement of all the donors. On the other hand, China is a lone ranger and an emerging economy, with more than USD 3 trillion in surplus, and with many internal problems as well. The DAC definition of aid - which is shared by its 24 exclusive members including Australia - sees development as the "flows of official financing administered with the promotion of the economic development and welfare of developing countries as the main objective, and which are concessional in character with a grant element of at least 25 percent (using a fixed 10 percent rate of discount). By convention, ODA [Official Development Assistance] flows comprise contributions of donor government agencies, at all levels, to developing countries ("bilateral ODA") and to multilateral institutions. ODA receipts comprise disbursements by bilateral donors and multilateral institutions. Lending by export credit agencies with the purpose of export promotion - is excluded" (OECD, 2003).

This paper is not meant to address the merit of the economic analysis of the definition. Nevertheless, a brief parenthesis is needed. In fact, the grant element of $25 \%$ (with a fixed 
$10 \%$ rate of discount) makes a loan a form of development assistance. However, a loan with a $25 \%$ of grant element could be more expensive than a loan taken at a private bank. Why should this happen? This is because the definition was structured in the 1970s, when interest rates were very high. Today, however, loans are linked to the London Interbank Offered Rate, which hover between 1 and 4 per cent (Bräutigam, 2011). This means that a private loan could have an interest rate twice cheaper than a loan given as aid. Therefore, the concessionality of loans given by the DAC donors could be put into question. Such a definition of aid assistance is not used by the International Monetary Fund and the World Bank, which rely on a higher grant element of $35 \%$ and use current commercial rate. Nevertheless, this problem is not the core matter of this paper that points out more on value and norms behind aid assistance. Therefore, aid is given under the form of loans and grants for the economic development and the welfare of developing countries. This definition is shared by the Western donors and in 2000 they gathered in New York to promote and sign the United Nations Millennium Declaration. This declaration was signed by all members of the UN, which is committed to implement it. On this occasion they agreed to eight goals of development, the so called Millennium Development Goals (MDGs), which pointed out the need to fight poverty, health issues, gender inequality, to promote environmental sustainability and global partnership. On that occasion too, countries agreed to give in aid $0.7 \%$ of the gross national income.

The DAC notion of concessionality also emerges in the Chinese definition of development assistance. China, in fact, has been providing aid to Southeast Asia through low-interest loans, trade and investment agreements, building of infrastructure, and also it has been providing them without conditional clauses, unlike the DAC donors (ex. democratic reforms, liberalization - which set their agendas following the principles of the Washington Consensus) (Lum, Morrison, \& Vaughn, 2008). The Ministry of Commerce is in charge of giving aid. It does so through the China Export Import Bank (Eximbank), which also takes care of a mix of factors: diplomacy, development and business. In fact, aid assistance is for China a tool to develop long term relationships with the recipient countries and possibly also business interests in the long run.

What falls under development assistance has been listed in the 1998's "Budget Management of Foreign Aid" issued by the Ministry of Finance of China. The budget affirms that the following can by funded as aid assistance: a) plants, general goods, military goods, and cash provided to recipient countries; b) training expenses of trainees accepted from recipient countries and salaries of experts and administrators sent to recipient countries c) cost of interest subsidies for concessional loans; d) funding of specified items in the portion borne by Chinese firms in foreign aid funded joint investment and cooperation projects; e) administrative charge paid by the firms to which aid projects have been contracted out and fees for their services acting on behalf of the government (Kobayashi, 2008).

By being a tool of diplomacy aid plays an important role for China. It is a tool to make relationships stronger, and on this ground China potentially offers aid to each country with 
which it has established formal diplomatic ties. However, Eximbank only offers those loans to creditworthy countries. For less creditworthy countries, however China offers to build tangible projects. For example, has China built a geothermal power project in Kenya, and the Ministry of Foreign Affairs in Timor-Leste. Other trustworthy countries receive loans and grants, ie. Botswana, which is now an upper-middle income country. Western donors could argue at this point that China gives aid in exchange for trade, oil and resources. Deborah Bräutigam (2009, p. 281) contends this by affirming that "the existing evidence suggests that China does not use its official foreign assistance budget to support bids for oil investments or natural resource concessions". However evidence suggests the opposite. China's interest in Timor-Leste does suggest a bid for oil; also the fact that China secures its loans in less trustworthy countries with oil and resources which would be a sign that China's interests are not different from those of the West. China's need for resources and raw material is well known; however, in 2005, Timor-Leste had already signed an agreement with Australia to explore the off-shore fields. In particular, the agreements between the two countries were about dividing all the profits of the Timor Gap (Wright, 2008).

Nevertheless, what China gives to another country through the Eximbank has the objective to "promote economic development and improve living standards in developing countries, and to boost economic cooperation between developing countries and China" (Bräutigam, 2011, p. 4). Overall, aid concessionality is emphasized by the DAC donors as well as by China, moreover they both offer export credits, which, however, are not considered as official assistance. Therefore the core definitions of development assistance are in summary pretty similar.

\section{How China Acquired the 'Trust' of the Timor- Lesteese Government}

Newspapers have widely covered the Australian government's disappointment at TimorLeste turning to China for aid and military support. Australia is the traditional donor par excellence together with the USA and the EU institutions, in Timor-Leste. Australia made the rules and set the agenda for global development with the DAC. However, Australia has proved that commitment is one story and disbursement is another story. They should match each other, but this is not always the case. Timor-Leste is a country in need, and when the local government realized that Australia was not a totally reliable partner, it turned to China to address some of the imminent and long term challenges. Figure 1 shows the problem.

Since Timor-Leste's independence in 2002, Australia had committed itself to give a specific amount of aid, but which was not disbursed in total, especially during the key years of 2005, 2006 and 2007. In these three years, Timor-Leste passed through a serious period of instability. Turmoil erupted between the military and a foreign intervention was necessary. Australia, Malaysia and Portugal deployed soldiers to try to maintain stability. This happened because Australia's aid was attached to government effectiveness, and during the turmoil usually local governments fail to maintain control of the country. Therefore, 


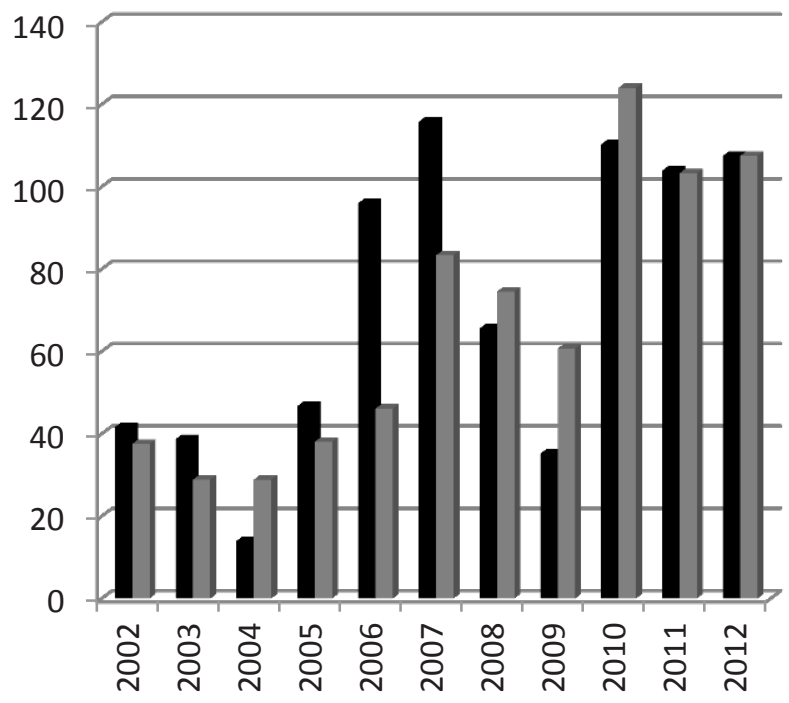

Australia's

Aid to Timor-

Leste (USD

million)

- Commitment

Disbursement

Source: OECD

Figure 1. Australia's Aid to Timor-Leste

Australia reduced aid to encourage the country to demonstrate better governance. However, Australia, since 9/11, has also committed to support the US's unilateralism, and the relative NATO operations. This move has been joined by most of the DAC donors. This has clearly affected their capacity to disburse the amount of aid promised to developing countries. In fact, the war in Afghanistan cost Australia AU\$7.5 billion, and the lives of many soldiers (Brissenden, 2013).

Moreover, when countries revise their annual budget, it often results in cost cutting and frequently, results in aid reductions. Just recently, Australia approved a new budget cut on aid of AU\$ 650 million, while military expenditures increased (Hall, 2014).

When traditional donors cut aid, they create concerns in the recipient countries which heavily rely on foreign assistance. Timor-Leste is an aid dependant country, and particularly in 2006 during the political crisis, aid and support were extremely needed. This was the moment in which China acquired the trust of the Timor-Lesteese government. Food scarcity, and the reduction of Australia's support, allowed China to step in. The Beijing government donated 4,000 tons of rice and 500 tons of cooking oil (People's Daily, 30 ${ }^{\text {th }}$ May 2006). This helped the Timor-Lesteese government to ease the population's and refugees' demand for food. Since Timor-Leste's independence, the Beijing government has looked into economic opportunities in the country. Strategic reasons were of utmost importance for the One China 
Policy. In fact, before its independence, the first president of Timor-Leste, Xanana Gusmao, claimed that China was a reliable friend, and he committed the little tiny Timor-Leste to a One China Policy (Storey, 2006).

China's aid was particular evident in developing infrastructure. Nowadays, five main buildings in the capital of Timor-Leste, Dili, are financed by Chinese aid. This has boosted Timor-Lesteese self-esteem, and it was seen as a practical and visible form of aid. This has led the current Timor-Lesteese Ambassador to China, Vicky Tchong to claim that: "We can get almost anything we want from China; all we need to do is to ask" (MacauHub, 2014).

\section{China's Relations with Timor-Leste}

China established formal diplomatic relations with Timor-Leste since its independence on 20 May 2002. However, China has had relationships with Timor-Leste leaders since the 1970s. When Timor-Leste was invaded by Indonesia on 7 December 1975, most European countries like Australia, the USA and even Russia avoided taking a stance on the invasion. Timor-Leste was a small region with a small population, and in the global vision it appeared to be much better for it to be annexed to Indonesia than see it struggle independently. At that time, Canberra and Washington were afraid of the spread of communism. By being alone, Timor became vulnerable to the interests of the Chinese, and the communist thinking of Mao Zedong's followers. Such a way of thinking has been confirmed by one of the documents of the Australian Ministry of Foreign Affairs, Australia and the Indonesian Incorporation of Portuguese Timor.

The Chinese have been far more prominent in showing support for Timor-Leste, particularly when they intervened at the United Nation Security Council to raise concern about what was happening in the country. The Chinese even recognized the first claim of independence of Timor-Leste after declaration on 28 November 1975. Moreover, from the 1970s, the two leaders of the independence movement in exile, José Ramos-Horta and Mari Alkatiri, have been to China several times. Unfortunately, at that time not even the USA cared about the human rights abuses in Timor-Leste. This seems a paradox in many ways considering the USA is the "chief" master in promoting human rights, and given the current human rights abuses occurring in China.

But what is less known is that since the Portuguese left after the Carnation Revolution in April 1974, China provided Timor-Leste diplomatic and financial support to the resistance movement. This is probably something that was known by the foreign intelligence of USA and Australia, and which is why they were afraid of communism spreading to Timor-Leste. Timor-Lesteese were basically alone in their fight for self-determination. No Western country was supporting their cause, even though the Timor-Lesteese had helped the Australians in the fight against the Japanese during WWII. In such a contest, in the 1970s, Timor-Lesteese 
pleaded for help from China who in turn tried to provide the resistance with a variety of light weapons. These weapons, however, were blocked by the Indonesian army and the Australian naval force. Only formal Portuguese colonies were supporting the cause of Timor-Leste. Therefore, the weapons were shipped by the Chinese to Mozambique, awaiting a clearance of the conditions in Timor-Leste in order to be delivered. This, however, did not happen. Such information was covered up by the media at that time. In Australia, the government did not want to upset Indonesia, because they were waiting to sign an important agreement for the exploitation of the oil of the Timor Gap. Such agreement later allowed Australia to fully exploit the field (Horta, 2009).

This strong interest for Timor-Leste to gain independence as demonstrated by the Chinese, was effectively motivated by the foreign policy of Mao's epoch. At that time China supported revolutionary movements as a way to undermine Western imperialism. However, Mao died in 1976, which made China more flexible in terms of foreign policy. Its moderate approach shifted its foreign interests, and at that point China forgot about Timor-Leste and accepted its incorporation into Indonesia.

Even in such a context, China maintained some relationship with those who visited the country during the 1970s, in particular with Mari Alkatiri, who then became the first prime minister of Timor-Leste. Alkatiri has always shown fondness of the Chinese, and in 1997 he was officially invited to attend the ceremony of the handing over of Hong Kong to China.

Later in 1999, there was the referendum for independence of Timor-Leste, where the population highly supported the separation from Indonesia. China immediately recognized the results and renovated its support to a free Timor-Leste, sending 55 civilian police to support the peacekeeping mission. This has been the first time China has deployed its police to a foreign ground. However, the decision was not without pain. Russia and China are known to be reluctant to intervene in overseas missions. However, within the Security Council, strong countries pushed Russia and China to accept the peacekeeping mission called International Force for Timor-Leste (INTERFET) led by Australia. Their concerns were related to internal issues with Chechnya and Tibet at that time (Van Walsum, 2002).

The Chinese were reluctant towards the Timor-Leste mission because they feared the new government would recognize Taiwan. In fact, the Taiwanese government tried to open a Taiwanese Trade and Cultural exchange office in Dili, but the plan was clearly opposed by the Chinese. However, the Chinese obsession about Taiwan was clearly just an obsession. No one within the Timor-Leste government would have turned its back on China, by recognizing Taiwan. It was also true that by being reluctant in establishing a peacekeeping force, the Chinese government lost its good image in the eyes of some important members of the future Timor-Lesteese government. Alkatiri understood that China was not reliable; this is why during his term as prime minister he tried to establish strong ties with other big neighbours such as Malaysia, Thailand, South Korea, the EU and the USA (Horta, 2009). 


\section{Concepts of Chinese Aid: Principles and Practices}

When dealing with Chinese aid in Timor-Leste it is quite complicated because there is not a strategic plan specific for the country. All the statistics scholars use are mostly based on data provided by the OECD and the DAC donors. However, the Chinese strategy applied in Africa is the same that is applied in developing countries in Southeast Asia.

Therefore, generally speaking, Chinese aid to Timor-Leste is based on two main principles. First, no interference in the affairs of another country; hence respect for sovereignty. Second, aid has no conditions attached to it. They are both very relevant and innovative approaches to aid. The second in particular would be very attractive for Timor-Leste given the fact that Australia's aid has been criticised for having so many conditions attached to it. Nevertheless, China's aid has "no strings attached", such as no push for democracy or economic reforms (Wang, 2010).

Mutual benefits and equality are also core values of the Chinese aid practice, expressed in the 2011 White Paper. This white paper deeply assesses the opportunities to increase bilateral relationships between donor and recipient. China sees aid as a way to start cooperation between countries which can bring further economic benefits in the long run. However, it is relevant to see how the aid decision-making process is structured.

Section V of the White Paper states that the decision-making power about foreign aid lies with the government of the People's Republic of China (PRC). But in order to strengthen the aid management the Chinese government has since then given authority to specific bodies to oversee the aid management. Currently, "the Ministry of Commerce (MOFCOM) of the PRC is the administrative department authorized by the State Council to oversee foreign aid" (China's Information Office of the State Council, 2011). The MOFCOM, by being in charge of the foreign aid structure, takes care of "foreign aid policies, regulations, overall and annual plans, examination and approval of foreign aid projects and management of the project execution." (China's Information Office of the State Council, 2011)

Chinese aid remains a bilateral way of relationship with recipients. The Ministry of Commerce also analyses what opportunities can arise following the aid assistance period. A major role is also in the hands of the Ministry of Foreign Affairs of China, which is involved in policy decisions and international initiatives for aid. In particular the Ministry of Foreign Affairs takes care of the relationship with the local government of the needs expressed by the local people, which are then communicated to the MOFCOM, through the Chinese Embassy in Timor-Leste, (Lancaster, 2007). The MOFCOM, then, establishes projects and funds to be spent, which are delivered through Chinese companies involved in Timor-Leste and with the support of the Chinese Economic and Commercial Attaché in Timor-Leste. The government, then, through the Eximbank gives loans and grants again with the support of the local Chinese Embassy in Timor-Leste. The whole process is solidified by the state visits, which are the glue to keep the bilateral relationships on the right track. This is why 
the Chinese have invited the Timor-Lesteese government on several occasions and which in turn received the visit of the vice-Chinese premier.

The choice to hand the aid management over to the MOFCOM has been based on the need to develop trade ties. In fact, while China does not attach any political strings to its aid, the government thinks in the long term benefits out of trade. Therefore, the link between foreign aid and trade is not a subtle story, but instead an engine which spurs Chinese interests in the world. Timor-Leste with its oil fields and with the needs of infrastructure and basic needs is a country that can bring long term benefit to China as well. Hence, the core idea of Chinese aid to Timor-Leste is very easy. China gives aid to Timor-Leste, and although it is not tied to any specific political measures, in the long run China will benefit by established trade ties with the Timor-Lesteese. However, the current strong presence of Chinese in the country could potentially spur resentment amongst the locals. Resentment against Chinese in Africa is very common; for example in 2010 in Zambia two Chinese supervisors were injured by about a dozen local mine workers who were protesting for better labour conditions (Knaup, 2010).

Aid, as mentioned above, is given under the form of grants, interest free loans, low interest concessional loans (giving also subsides to the interest rates when needed). In the case of Timor-Leste, aid has been given mainly in material grants (infrastructure for example) and loans and grants. The percentage is small in comparison to the DAC donors, but the political debate is blistering the media (The Australian, $16^{\text {th }}$ April 2008) in Timor-Leste and Australia. However, China has also merged foreign aid and investment in Timor-Leste. In fact, the country has been conducting field studies for further oil exploitation. The country is also investing in other sectors, especially the private sector and tourism.

Nevertheless, Chinese aid is difficult to quantify. While the DAC donors always publish statistics about the amounts of aid, China does not have a similar approach. Few statistics are published in terms of Chinese Yuan and never in US dollars, so quite often there is confusion about the amount of money involved. The other point is that China leaves the choice to the recipient country to publish reports and assessments.

The Western aid mania with aid statistics, was not only about the terms of funding, but also reports on the outcomes. In fact, Australia's aid to Timor-Leste has mostly aimed at reducing poverty and mortality rates, while Chinese aid pointed more to its visibility. However, the benefits of Australia's aid are well acknowledged by the rural population of Timor-Leste.

As seen, Chinese aid practices are based on mutual benefits for donors and recipient. In fact, China aims through foreign aid to gain access to the recipient market. How? By gaining labour and engineering contracts from the recipient country in exchange for the assistance provided. In other words, as Berthelemy (2011, p.16) puts it Chinese "development assistance is usually granted in kind, while financial assistance is given to finance contracts that are 
implemented by Chinese companies". This trend is highly visible in African countries, such as Angola. Nevertheless, also Timor-Leste has been affected by the same policy. Chinese foreign aid has, in fact, been secured by contracts managed by Chinese companies.

China went much further in this concept of mutual benefits, by giving a much stronger role to the old trade form of barter. The Chinese, therefore, offered aid on the assurance that they could undertake onshore oil research, which later did not have the expected outcome. The original plan was to build inland facilities, but unfortunately it did not work. While China's need for resources shapes its aid policy practices, it is true that such practices may be undermined by the presence of the DAC donors. The strong Australian presence in Timor-Leste makes the barter game much more difficult for China. In Africa, instead, it has been slightly easier. In Gabon, for example, China was able to secure the exploitation of iron ore fields in return of loans and grants for the Gabonese public expenditure (Davies et al., 2008).

Although, Deborah Bräutigam argues that Chinese aid cannot be linked to its needs of raw materials and resources, current Chinese practices would show the opposite. Moreover, what Bräutigam affirmed, is highly debatable and contradictory to what she also claims, that China's aid is almost entirely tied to trade conditions (Bräutigam, 2008, p. 204). So, although it is not tied to democratic achievement, and/or structural adjustments - as in the case of the DAC donors - it is tied to business opportunities for China. This interest has been proved by Davies et al (2008, p. 19) which established that China assures its loan with collateral. Now, it is highly contradictory to split trade interest from resource interests. Why should China be interested in giving aid for trade but not for resources exploitation? Chinese aid, whether for trade opportunities, or for oil bids, is tied to economic goals. Timor-Leste's experience tells researchers exactly that. China tried to exploit onshore oil. Most of the local infrastructure was built exclusively with Chinese goods and labour. Many Chinese workers remained in Timor-Leste. In fact, the strategy of giving aid in the form of infrastructure has been based on the idea of relying on Chinese labour and goods, which clearly did not contribute to spur local employment. Most of the Chinese workers remained in TimorLeste to seek further economic opportunities, and today they compete with the locals to find jobs. This competition does not benefit the low and middle classes of Timor-Leste. Moreover, it seems the Chinese Embassy is helping Chinese companies to gain access to the Timor-Lesteese developing market. Substantially, although the different principles on which Chinese development is inspired, the aid practice shows that it is given for strategic interest, which is not in terms of regional strategy, or geographic proximity as it is for Australia, but to develop further economic opportunities for China. By consequence, locals have labelled China as the new potential colonial power. Such a negative perspective could be counter-balanced if the aid was creating local jobs. Nevertheless, in the perception of the Timor-Lesteese this is irrelevant because China brings into the country Chinese labour and Chinese material. This is why, despite the huge infrastructure projects of China there was no benefit to the unemployment rate. It is currently around $15 \%$ of the labour force ages 15-24. (Index Mundi) 
By giving aid for trade, someone could argue that China only invests more in resourcerich countries because of the trade opportunities. However, the Chinese government has a different perspective. In fact, by giving aid on the idea of mutual benefits and sovereignty respect, it has put all the countries, small medium and large, on the same ground. Hence, China treats all the countries as equals, but this does not mean that China's aid motive is out of interest. On the other hand, aid investments in Africa show that China is investing where no other country is. For example, the Democratic Republic of Congo lacks infrastructure and China is helping the government to start with that infrastructure. Therefore, in the view of Bräutigam (2009, p.146), China is filling the infrastructure gap, something other donors do not want to worry about. This is what China has done in Timor-Leste in the last decade with the building of public infrastructure. Australia, instead, focuses aid more towards the MDGs. Therefore, although in Dili, the local population cannot see any huge building signed by the Australian government, in the periphery of the city and in the rural areas they can see the benefit of health improvements, water and sanitation facilities.

Nevertheless, China has provided much less aid to Timor-Leste than Australia and other DAC donors have been providing for decades (La'o Hamutuk, 2011). China until recently has been concentrating on giving aid to Timor-Leste in the form of infrastructure. China built the Ministry for Foreign Affairs, the Presidential Palace, and also its embassy in the main street in Dili. By spending an average of USD 20 million for those buildings - with quite large and self-promoting labels on the facade of the buildings stating that they were built by China's aid - China has spurred its image amongst the local population as a donor that was doing much more than the Australians (and the DAC). China went on to build houses and offices for the Timor-Lesteese Ministry of Defence (Forças Defesa Timor Lorosae FDTL).

In this last decade, China has also focused on giving Timor-Lesteese the opportunity to train in China. Timor-Leste, as a young nation, lacked the know-how to build national facilities. This is why China offered the opportunity for intensive skill-building courses on its mainland. These training sessions aimed at furthering knowledge in public administration, health, tourism, economics, construction and technology.

Although Timor-Leste experienced several political unrests, the country managed somehow to spur growth at an average of $8 \%$ a year. In this context, China decided to make bilateral relations a source of benefit for its export. This is why in 2008 China was already the fourth largest trade partner of Timor-Leste with around USD 10 million in trade (Timor-Leste Government).

\section{Economic Impact of Chinese Aid in Timor-Leste}

Kingsbury (2012), in his analysis on the presence of China in Timor Leste, says that aestheticism seems more attractive to locals than projects that maybe effective, but not visible. In fact, he reports what the locals have said about the buildings built under the 
Chinese aid projects: "Look what China has done for us. What has Australia even done for Timor-Leste?" (Kingsbury, 2012). It seems that locals have ignored the millions in aid invested by Australia in Timor-Leste. This kind of contradiction between what locals see about Chinese aid, and what effectively Chinese aid did to improve the quality of life of the locals, is highly contentious.

Chinese aid in Timor-Leste is based on "practical, realist and achievable objectives" (Brant, 2011, p.8-9). Timor-Leste even with a small population is a market consumer because of its willingness to develop fast. China aims to spur "economic growth and implementing a development model based on each country's specific requirements and circumstances", Brant (2011, p.8-9) affirms. This intention to spur growth has been shown by China's commitment to build infrastructure in Timor-Leste. China and Timor-Leste have been both enthusiastic about the economic possibilities behind this bilateral relationship. China pushed Timor-Leste to accept its help and at the same time attempted to make a self-gain out of the story. China's soft power, therefore, has pushed the Timor-Lesteese government towards its aid agenda (Kingsbury, 2012).

In fact, Horta (2009) made a study about the economic impact of Chinese aid in TimorLeste by analyzing the different sectors. It starts its discussion about the energy sector, which is probably the one that was most attractive to the Timor-Lesteese government due to its need for energy.

PetroChina has been conducting seismic studies to understand the extent of onshore oil deposits. This study has cost USD \$1.7 million, and Timor-Leste expected China to bid for the building of a new processing facility and transportation from the interior to the coastal area. However, as the study did not bring the hoped outcome, PetroChina decided not to commit itself to such a big plan with the risk of losing rather than gaining. But there are many more reasons than just this. The Chinese wanted a full commitment by the Timor-Lesteese government to guarantee exclusive rights to PetroChina over the oil and natural gas onshore resources. However, Mari Alkatiri, the then prime minister, dismissed the Chinese offer because they refused to disclose information about the potential of the onshore deposits. Nevertheless, he maintained a good relationship with China in order to counter-balance the Australian presence in the country and in the Timor Sea. Alkatiri has been a smart political figure in defending Timor-Lesteese interests. What he then did was to contact Indian and Malaysian oil companies to start further studies on the onshore fields (Nicolau \& Scheiner, 2005) \& (Rotherham, 2004).

The other political speculation about economic development was related to the supposed willingness of China to build process facilities for natural gas in Timor-Leste. This would have undermined the Australian plan to build the same facilities in Darwin in order to create jobs in the Northern Territory. Nevertheless, Australia and China have a strong bilateral relationship at the point in time in which China became its largest trading partner. 
However, the Australian government does not cope well with China's presence in the areas fundamental for Australian security (Dodd, 2008, September 30). Although Australia has strong economic ties with China it does not want to have another powerful country competing in centre of its interests.

On the other hand, Australia should not be worried about its economic tie with Timor-Leste because José Ramos-Horta affirmed in 2013 that "Today we enjoy unique excellent relations with our closest neighbours, Indonesia and Australia" (The $13^{\text {th }}$ D.T. Lakdawala Memorial Lecture, Delhi, $3^{\text {rd }}$. Dec. 2013). However, he went on admitting that Timor-Leste had to develop the closest possible relationship with China. Of the same token, China will never try to damage any relationship with Australia, especially in consideration of the complex economic interdependence.

Yet, the need for resources plays an important role. China has interests in oil and gas as much as in manganese and blue marble deposits, and also fisheries. Fisheries in particular raised concern in the Timor-Lesteese government. Chinese have been able to obtain fishing rights in the Timor-Lesteese economic zone, however the Timor-Lesteese are not able to control the numbers of Chinese vessels and how much they fish in the Timor-Lesteese zone. It has been calculated that the loss is huge for Timor-Leste because of the over exploitation of the fishing zone. The current situation presents China as an indiscriminate thief of the coastal zone of Timor-Leste (Storey, 2013).

Nevertheless, China's aid has been quite controversial on more than one occasion. In fact, while Australia has offered to patrol the cost of Timor-Leste free of charge, China has offered military machinery for a "cheap" price. Timor-Leste, therefore, signed a contract for more than \$20 million to buy eight Chinese military jeeps, and two coastal patrol vessels. The political issue arose because the government signed the agreement without a formal call for application. The lack of transparency also raised concern in Australia. Such an internal move by the Timor-Lesteese government seems to have been done as revenge against the Australian government for lack of respect regarding the country's sovereignty.

Moreover, the suitability of the vessels has been put into question. The deal between China and Timor-Leste has been categorized under a form of aid, because China gave a good "discount" for the vessels and provided free training for the Timor-Lesteese personnel. However, at a later stage, it became clear that those vessels were not suitable for rough seas and tropical weather. Moreover, they were based on an old project structured in the 1960s and made for the conditions of China's Sea. These circumstances caused clashes between Australia and Timor-Leste, but it also raised concerns within the government of TimorLeste about the quality of Chinese machinery as well as about the willingness of China to really help Timor's development. Such a state of affairs has made it clear to the TimorLesteese government that there is a distinct need to look for other trustworthy and respectful partners. Later, the Timor-Lesteese government signed a contract with South Korea for 
two extra vessels. South Korea, in return for the contract, also gave Timor-Lesteese several military machineries and smaller vessels as a gift.

Chinese aid to Timor-Leste caused further doubts when a project to electrify the country turned into a major concern for people's health and the environment. The original aid project which aimed at exploring renewable sources such as wind and sun became an incubus because China made it clear that in order to provide electricity to remote areas it would be using heavy oil power plants. Timor-Leste was uncontaminated, and such heavy oil plants were highly dangerous because of the oil burnt. Moreover, the plants were more than 20 years old. Once again, the Timor-Leste government, as in the case of the military vessels, did not publish any information about the contract with the Chinese (La'o Hamutuk, 2011).

Although China increased its aid assistance on a year basis, the overall figure is still modest in comparison to other donors. In 2013, China committed to 100 million yuan (USD 16 million) in aid (MacauHub, 2014), while Australia has an annual commitment of USD 100 million. Portugal, in spite of its economic crisis provided USD 24 million in aid (OECD Chart). However, even with such modest aid, China created strong ties with Timor-Leste. Chinese aid is loud, while Japanese aid is not. Japan has spent a consistent amount of aid in Timor-Leste, but the Japanese government's discretion has made its influence much less visible among the local population. It could be argued here that Chinese aid is a way of showing off what Chinese can do, to simply promote the Chinese and China. Discretion is definitely a good attitude to keep international relations going on a peaceful track. Loudness of Chinese aid is not welcomed by the DAC donors, and it also risks undermining the effectiveness of different forms of aid projects by the different donors. Media has also created this dichotomy between Chinese and Australian aid. In fact the New York Times have quite often published updates on the situation in Timor-Leste, and pointed mostly to the infrastructure built by the Chinese, rather than to focus on other donors' projects (Mydans, 2007), ie, the Japanese project to modernize Dili's harbour and the construction of the first Timor-Lesteese highway.

On the other hand, Chinese diplomats had an important role in developing economic ties between China and Timor-Leste. All the ambassadors that served in Timor-Leste were fluent in Portuguese, by having previous experience in Portuguese speaking countries. They were much more active in comparison to their Western counterparts, by talking and listening to the needs of the local Timor-Lesteese government. They built strong diplomatic ties, aimed at economic gain for both China and Timor-Leste.

\section{Chinese Aid to Timor-Leste: Helping the Poor or Gaining Political Consensus?}

China has achieved its aim to promote its own form of development delivery in TimorLeste. As seen, China's principles for aid giving differ from the ones of Western countries. China was able to deliver a new aid model, which seems politically attractive to recipient countries. 
Nevertheless, it is quite complicated to assess if Chinese aid has also impacted the life of the poor. The framework created by the World Bank to assess aid effectiveness in Low Income Countries Under Stress (Manor, 2007) is of difficult apply to Chinese aid. Such a framework relies on quantitative data, which is available for aid delivered by the DAC donors. This framework is strictly Western made; therefore applying it to Chinese aid would be difficult, if not impossible.

Overall, as above mentioned above, Chinese aid is something visible in Dili, while it is not in the rural areas. In fact, China has concentrated its aid policy mainly in the capital, where diplomacy and foreign policy play an important role. Therefore, while the population of the city seems to be impressed by those huge buildings that are definitely shaping the skyline of the city, the population of the rural areas might have a different perspective. In brief, China did not invest in water and sanitation, in health, or other areas of basic needs. Consequently, it is impossible to estimate if Chinese aid has reduced infant mortality rate, malaria, and dengue fever. Moreover, when in 2006 there was the political and military arrest in Timor-Leste, China provided tons of rice and cooking oil during this period of food scarcity. However, it did not invest to give the local Timor-Lesteese the instruments to produce the food by themselves. There was no investment in helping the Timor-Lesteese to improve the their rice production. However, the policy of giving food during times of food scarcity is an incredibly soft power tool, because the Timor-Lesteese government was able to avoid further unrest and to gain time to re-establish food security across the country. The same has been done by the Chinese in another former Portuguese colony in Africa: Guinea Bissau (Miller, 2006).

China knew how to boost its image vis-a-vis Timor-Leste. Consequently, it appears that Chinese aid is more effective in political terms than in poverty alleviation. A key event to be noted is that in August 2008 during the opening ceremony for the Chinese Olympics, José Ramos-Horta, at the time President of Timor-Leste, has been formally invited by the Chinese government to attend the ceremony. On that occasion, Chinese President Hu Jintao met Ramos-Horta in a private session. Furthermore, out of more than sixty Heads of State, Hu Jintao met only Ramos-Horta and the President of the Philippines (Xinhua, 2008). What $\mathrm{Hu}$ Jintao did, was a gesture of respect for a small country like Timor-Leste, which is often disregarded by the Western countries. The meeting was a strong sign of Timor-Leste's recognition as a nation that can talk with another state on an equal base. This meeting had a strong resonance in Timor-Leste, giving the Timor-Lesteese a strong sense of identity on the international stage. Therefore, Chinese diplomacy becomes the tool to buy consensus internationally, and Chinese diplomats, as well as Chinese politicians have demonstrated how to play the game in foreign policy.

Overall, Chinese aid has been definitely visible in Dili, while in the rural areas there has been no specific effect. This was mostly due to the limited amount of money involved. It is also true that Australian aid to Timor-Leste was much bigger in figure and its impact was much more visible to rural Timor-Lesteese. In the next decade, however, Chinese aid 
could have an increasing impact on the life of the Timor-Lesteese. History will tell if this aid will be in the interests of the poor, or just another way to have access resources and a fast developing market, or if it is in the best strategy of helping the recipient country and spurring trade opportunities.

\section{Conclusion}

In conclusion, Chinese aid giving gave Timor-Leste an alternative. China came to TimorLeste with respect, it did not interfere with the already fragile local government, it proposed an amicable relation, and it showed its presence in the country through tangible aid projects. China built the Timor-Lesteese Ministry of Foreign Affairs; China provided navy patrol and power generators. In spite of the criticism the Chinese have demonstrated to the local politicians that China was doing something for them and that it was respecting the sovereignty of the local government. In this sense, the principles of self-reliance, mutual benefit, and non-interference seem to be very much appreciated by the government in TimorLeste. However, by being an alternative aid provider, China should not interfere much with the Australian aid regime, as long as the Timor-Lesteese population maintains trust in Australia. Therefore, China is not undermining the principles of Western aid. However, Australia should take into consideration that the principles of non-interference might be a very successful strategy in foreign policy, rather than performing constant intervention in the internal affairs of Timor-Leste.

The Australian aid based on the promotion of good governance, democratic liberalism and poverty reduction is still appreciated by the population and the government of Timor-Leste. However, a global view, updated with the possibilities of establishing also mutual benefits and effective partnerships, as China is attempting to do with the developing countries, is what is much needed. As Easterly pointed out, "Aid cannot achieve the end of poverty. Only homegrown development based on the dynamism of individuals and firms in free markets can do that" (Easterly, 2006, p. 368). China, with the principle of mutual benefit, is becoming an attractive donor for developing countries. Nevertheless, from the perspective of international relations, Chinese aid in Timor-Leste has not been challenged, neither has its intention to do so by the leading role of soft powers such as Australia. However, China's presence has given rise to the misleading perception that China is a threat to Australia or the USA, Japan, etc. The rise of such beliefs have been linked to the ideological incompatibility of China's values with Western values, as well as to the striking economic growth, which will eventually lead China to become a world superpower.

Finally, Australia should not be bothered about the "safety" of its plan of good will in the development of Timor-Leste. However, to maintain the good relationship with TimorLeste, Australia needs to stop bullying its little neighbour. An updated aid agenda is needed, and it has to be based on respect for the national sovereignty of Timor-Leste. 


\section{References}

Berthelemy, J. C. (2011). China's engagement and aid effectiveness in Africa. African Development Bank Group.

Brant, P. (2011, October 14). Is China challenging traditional donors' development policy? WhyDev. Retrieved from http://www.whydev.org/is-china-challenging-traditionaldonors-development-policy/.

Bräutigam, D. (2011). Aid 'With Chinese Characteristics': Chinese Foreign Aid and Development Finance Meet the OECD-DAC Aid Regime. Journal of international development, 23(5), 752-764.

Bräutigam, D. (2008). China's African Aid: Transatlantic challenges. The German Marshall Fund of the United States.

Bräutigam, D. (2009). The dragon's gift: The real story of China in Africa. Oxford: Oxford University Press.

Brissenden, M. (2013, December 16). In their words: Was Australia's role in the Afghanistan war worth the cost? ABC Online. Retrieved from http://www.abc.net.au/news/201310-29/was-australias-role-in-the-afghan-war-worth-it/5056376

China's Information Office of the State Council. (2011). China's Foreign Aid. Retrieved from Xinuanet:http://news.xinhuanet.com/english2010/china/2011-04/21/c_13839683. htm

Davies, M., Edinger, H., Tay, N., \& Naidu, S. (2008). How China delivers development assistance to Africa. Research paper by the Centre for Chinese Studies, University of Stellenbosch, South Africa.

Dodd, M. (2008, April 16). Alarm at China's influence in Timor. The Australian.

Dodd, M. (2008, September 30). Unease grows at the rise of China. The Australian.

Easterly, W. (2006). The White Man Burden: Why the West's Efforts to Aid the rest have done so much ill and so little good. New York: Penguin Press.

Enuka, C. (2010, December). The Forum on China-Africa Cooperation (FOCAC): A Framework for China's Re Engagement with Africa in the $21^{\text {st }}$ Century. Pakistan Journal of Social Sciences, 30(2). 
Hall, B. (2014, January 18). Government's \$650m foreign aid cuts slammed. The Sydney Morning Herald. Retrieved from http://www.smh.com.au/federal-politics/politicalnews/governments-650m-foreign-aid-cuts-slammed-20140118-311c5.html

Horta, L. (2009). Timor-Leste: The Dragon's Newest Friend. Research Institute on Contemporary Southeast Asia (IRASEC).

MacauHub. (2014, February 8). The Dragon and the Sleeping Crocodile. China and TimorLeste. MacauHub. Available at http://www.macauhub.com.mo/en/2014/02/08/thedragon-and-the-sleeping-crocodile-china-and-timor-leste/

Index Mundi. (n.d.). Timor-Leste Unemployment, youth ages 15-24. Retrieved from http:// www.indexmundi.com/timor-leste/youth_ages_15-24_unemployment.html.

Kingsbury, D. (2012, August 10). China's Interests in East Timor. Retrieved November 19, 2013, from Damien Kingsbury's blog at Deakin University in Melbourne. Retrieved from http://communities.deakin.edu.au/deakin-speaking/node/348

Knaup, H. (2010, December 9). Investment with Strings Attached: Cables Reveal Resentment at Chinese Influence in Africa. Spiegel Online. Retrieved from http://www.spiegel. de/international/world/investment-with-strings-attached-cables-reveal-resentmentat-chinese-influence-in-africa-a-733870.html.

Kobayashi, T. (2008). Evolution of China's Aid Policy. Working Paper - Japan Bank for International Cooperation (27).

Lancaster, C. (2007). The Chinese Aid System. Center for Global Development.

La’o Hamutuk. (2001, June 21). Is China aiding Timor-Leste, or vice-versa?. La'o Hamutuk

La’o Hamutuk. (2011, September 28). Power Plant and National Electrical Grid 2008-2009. La'o Hamutuk.

Lum, T. G., Morrison, W. M., \& Vaughn, B. (2008, January). China’s “soft Power” in Southeast Asia. Congressional Research Service, Library of Congress.

Manor, J. (2007). Aid That Works: Successful Development in Fragile States. Washington, DC: World Bank.

Miller, T. (2006, July 20). China becomes world's third largest donor of food. The Guardian. 
Mydans, S. (2007, July 26). Aid from China builds an Ally in Timor-Leste. The New York Times.

Nicolau, G., \& Scheiner, C. (2005, September). Oil in Timor-Leste. La'o Hamutuk.

OECD Chart, http://www.oecd.org/dac/stats/documentupload/TLS.JPG

OECD. (2003, August 28). Glossary of Statistical Terms. Retrieved from OECD: http:// stats.oecd.org/glossary/detail.asp?ID=6043

People's Daily. (2006, May 30). Timor-Leste thanks China for rice aid. Retrieved from: http://english.peopledaily.com.cn/200605/30/eng20060530_269752.html.

Perlez, J. (2006, May 30). Billions in aid brought Timor-Leste little. The New York Times .

Ramos-Horta, J. (2013, December 3). Speech: The 13th D.T. Lakdawala Memoria Lecture, Delhi. Retrieved from Ramos Horta: http://ramoshorta.com/2013/12/speech-the13th-d-t-lakdawala-memoria-lecture-delhi-india/

Riddell, R. C. (2007). Does foreign aid really work? United Kingdom: Oxford University Press.

Rotherham, S. (2004, December 9). Timor gets ready for petroleum exploration. Retrieved from Energy News Premium. Retrieved from http://www.energynewspremium.net/ storyview .asp? storyid $=32413 \&$ sectionsource $=\mathrm{s} 0$

Storey, I., (2006, August 15). China and East Timor. Good, but not best friends. China Brief. Retrieved from http://www.asianresearch.org/articles/2920.html.

Storey, I. (2013). Southeast Asia and the Rise of China. Routledge Security in Asia.

Timor-Leste Government. (n.d.). Retrieved from Timor-Leste National Statistics Office. http://dne.mof.gov.tl/

Van W. P. (2002, February 7). The East Timor Crisis and the Doctrine of Humanitarian Intervention. Asialink Seminar. The University of Melbourne. Retrieved from The East Timor Crisis and the Doctrine of Humanitarian Intervention: http://cms.unimelb. edu.au/asialink/archived/events/past/past_events_public/the_east_timor_crisis_and_ the_doctrine_of_humanitarian_intervention

Wang, A. F. (2010). China-Africa Political and Economic Relations in the 21st Century: an Analysis of China's new Involvement into Africa. Phd Thesis, Jilin, China: Jilin University. 
Wright, J. (2008, May 31). Risky Pipedreams for Timor-Leste. Asia Times Online. Retrieved from http://atimes.com/atimes/Southeast_Asia/JE31Ae01.html.

Xinhua. (2008, August 7). Chinese president meets president of Timor-Leste. Retrieved from XinhuaNet: http://news.xinhuanet.com/english/2008-08/07/content_9022640. htm

Way, W. (2000). Australia and the Indonesian incorporation of Portuguese Timor, 19741976. Melbourne University Press. 